\title{
PENGARUH EKSTRAK DAUN KUNYIT (Curcuma longa Linn.) SEBAGAI INSEKTISIDA ELEKTRIK TERHADAP MORTALITAS NYAMUK Culex sp. L.
}

\author{
Aseptianova \\ Prodi Pendidikan Biologi FKIP Universitas Muhammadiyah, Palembang, Sumatera Selatan \\ Corresponding author: Nasepti@yahoo.co.id
}

\begin{abstract}
Mosquito Culex sp. L. is a vector of elephantiasis disease, prevention effort of elephantiasis vector is usually done by using chemical and natural insecticide. In the leaves of turmeric can be used as a natural insecticide in the prevention of elephantiasis vector disease. The objectives of this research are (1) to know the effect of turmeric extract ((Curcuma longa Linn.) As electrical insecticide to mortality of Culex sp. L. (2) To know the concentration of turmeric extract (Curcuma longa Linn.) Which is effective to be used as an electric insecticide against mortality of Culex sp. L. expressed by the toxicity test of LC50 and LT50. The method used in this research is an experimental method with Completely Randomized Design (RAL) which consists of 5 treatments and 4 replications. Based on research result of turmeric extract (Curcuma longa Linn.) Have a very significant effect on mortality of Culex sp. L. with sig value 0,000 <sig value. 0.05. The probit analysis of LC50 of turmeric leaves extract on mortality of Culex sp. L. is $44,840 \mathrm{ml}$, meaning that at that concentration has occurred $50 \%$ mortality of total mosquito. The probit analysis of LT50 turmeric leaves extract on mortality of Culex sp. L. for 1.825 hours.
\end{abstract}

Keywords: turmeric leaves extract, mortality Culex sp. L. mosquito

\section{PENDAHULUAN}

Nyamuk merupakan serangga penggangu yang dapat menularkan berbagai macam penyakit berbahaya. Penyebaran berbagai penyakit oleh nyamuk merupakan suatu masalah kesehatan yang sangat serius. Di berbagai negara, nyamuk dapat menjadi vektor berbagai penyakit seperti malaria, demam berdarah, filariasis, dan chikungunya (Nindatu, 2011).

Kasus filariasis atau elephantiasis adalah penyakit parasitik yang terus meningkat kejadiannya sampai tahun 2012 di Sumatera Selatan. Filariasis disebabkan oleh 2 (dua) spesies utama cacing filarial, yaitu Wuchereria bancrofti dan Brugia malayi. Nyamuk ini beraktivitas pada malam hari (nocturnal) sehingga mengganggu ketenangan dan kenyamanan manusia pada saat tidur. Salah satu vektor penyebab penyakit filariasis adalah nyamuk Culex sp. (Oktiansyah, 2015). Upaya pengendalian penularan penyakit filariasis dilakukan dengan pengendalian vektor penyakit tersebut.

Palgunadi (2012) dalam Soegijanto (2003), menyatakan bahwa secara garis besar terdapat empat cara pengendalian vektor yakni secara kimiawi ,biologi, radiasi dan mekanik atau pengelolaan lingkungan. Salah satu pengendalian vektor penyakit filariasis dengan penggunaan insektisida alami. Insektisida alami merupakan solusi untuk mengurangi penggunaan insektisida kimia dalam menanggulangi vektor penyakit tersebut. Pemanfaatan insektisida alami dapat 
dilakukan dengan metode elektrik berupa liquid (cairan).

Anti nyamuk uap cair elektrik (liquid vaporaizer) adalah jenis anti nyamuk yang memerlukan pemanasan elektrik untuk bisa menguapkan bahan aktif dalam bentuk cair, tempat yang digunakan pada umumnya adalah berupa botol. Metode elektrik dipilih karena tidak menimbulkan asap dan debu serta cepat dinetralisir lingkungan dibandingkan dengan metode semprot dan oles (Galena, 2014).

Penggunaan insektisida alami secara elektrik cair (liquid), lebih praktis dan mudah cara menggunakannya serta lebih hemat dibandingkan dengan pemakaian anti nyamuk lain. Tumbuhan yang dapat digunakan sebagai sumber insektisida alami memiliki berbagai macam kandungan seperti saponin, flavonoid, tanin, minyak atsiri dan senyawa metabolit sekunder lain yang bersifat racun atau toksik terhadap hewan sasaran.

Penelitian Aseptianova (2017), membuktikan beberapa tanaman seperti daun mint, umbi lengkuas, sambiloto, babadotan, daun alpukat, daun salam, daun pucuk merah, dan daun zodia dapat dimanfaatkan sebagai insektisida elektrik dalam mengendalikan nyamuk DBD (Aedesaegypti L.). Salah satu tanaman yang mengandung bahan aktif biologis yang dapat digunakan sebagai pengendali alternatif yaitu tanaman kunyit (Curcuma longa Linn.).

Menurut Caragay (1992), daun kunyit mengandung minyak atsiri golongan monotepen, sesquiterpen, diterpen, politerpen, alkohol, flavonoid, aldehid, keton, ester dan eter. Selain itu, komponen minyak atsiri yang berhasil diindentifikasi diantaranya limonen, pinen, dan myrcene.

Septiana (2015), menyatakan bahwa selain bagian rimpang, bagian daun tanaman kunyit juga memiliki aktivitas antimikroba yang mengandung minyak atsiri. Kandungan minyak atsiri kunyit sekitar 3-5\%. Minyak atsiri kunyit terdiri dari senyawa $d$ - $\alpha$-peladren (1\%),d-sabien $(0,6 \%)$, cineol $(1 \%)$, borneol $(0,5 \%)$, zingiberen (25\%),tirmeron $\quad(5,8 \%)$, seskuiterpen alkohol (5,8\%), a-atlanton dan $\mathrm{\gamma}$-atlanton yang potensial digunakan sebagai insektisida alami pengganti bahan kimia dalam usaha membunuh larva nyamuk. Menurut penelitian dari utami (2014), membuktikan bahwa minyak atsiri efektif sebagai repelan nyamuk demam berdarah (Aedes aegypti L.).

Berdasarkan pendahuluan di atas penelitian ini dilakukan untuk mengetahui pengaruh ekstrak daun kunyit (Curcuma longa Linn.) sebagai insektisida elektrik terhadap mortalitas nyamuk Culex sp. serta Untuk mengetahui konsentrasi ekstrak daun kunyit (Curcuma longa Linn.) yang efektif 
Aseptianova: Pengaruh Ekstrak Daun Kunyit (Curcuma longa Linn.) Sebagai Insektisida Elektrik Terhadap Mortalitas Nyamuk Culex sp. L.

untuk digunakan sebagai insektisida elektrik terhadap mortalitas nyamuk Culex sp. yang dinyatakan dengan uji toksisitas $\mathrm{LC}_{50}$ dan $\mathrm{LT}_{50}$.

\section{METODE PENELITIAN}

Metode yang digunakan dalam penelitian ini adalah metode eksperimen dengan Rancangan Acak Lengkap (RAL) dengan variabel bebas yaitu konsentrasi ekstrak daun kunyit (Curcuma longaLinn.), sedangkan variabel terikat yaitu mortalitas nyamuk Culex sp yang terdiri dari 5 perlakuan dan 4 ulangan.

\section{Pengumpulan Data Penelitian}

\section{a. Persiapan Alat dan Bahan Penelitian}

Bahan yang digunakan yaitu daun kunyit, nyamuk Culex sp. Sedangkan alat yang digunakan gelas kimia, gelas ukur, timbangan, blender, penyaring, alumunium foil, erlenmeyer, spatula, pipet tetes, kotak uji, toples, buku, label nama, pena, kamera, alat elektrik, corong, gelas ukur, destilasi.

\section{b. Pengekstrakan Daun Kunyit (Curcuma longa Linn.)}

Langkah-langkah pembuatan ekstrak daun kunyit mengacu pada penelitian Mirnawaty (2012), yaitu daun kunyit sebanyak $1 \mathrm{~kg}$ yang dipilih sesuai kriteria peneliti, yaitu dipilih berdasarkan warna hijau muda serta tidak ada warna kuning pada bagian. Daun dipotong dengan menggunakan pisau, dicuci kemudian ditiriskan dan dikering anginkan selama hari. Daun kunyit (Curcuma longa Linn.) yang sudah dikeringkan kemudian dihaluskan dengan blender dan diayak sehingga memperoleh serbuk halus. Serbuk daun kunyit yang digunakan sebanyak 1000 g diekstraksi dengan cara maserasi yakni merendam sampel dalam pelarut etanol $70 \%$ perbandingan 1:4 pada tabung atau toples selama 1 kali 24 jam, ekstrak tersebut disaring untuk dipisahkan antara residu dan filtratnya. Filtrat yang diperoleh dari perlakuan sebelumnya kemudian dimasukkan ke dalam alat destilasi dengan suhu $70^{\circ} \mathrm{C}$ untuk memisahkan ekstrak daun kunyit dengan pelarutnya selanjutnya menampung ekstrak yang telah didapatkan di dalam erlenmeyer.

\section{c. Persiapan Sampel Nyamuk Culex sp.}

Nyamuk Culex sp.diperoleh dari koloni yang diambil di got atau parit berupa larva dan dipelihara dan dikembangbiakan untuk menjadi nyamuk dewasa. Nyamuk dewasa yang digunakan untuk penelitian dengan menggunakan 5 perlakuan dan 4 ulangan, dalam satu ulangan membutuhkan 15 ekor nyamuk dengan umur 3-5 hari.

\section{d. Cara Kerja Penelitian}

Langkah kerja penelitian yang dilakukan yaitu aquades dan ekstrak daun kunyit (Curcuma longa Linn.) ditakar sesuai dengan konsentrasi yang telah ditentukan.konsentrasi ekstrak dimasukan ke dalam botol alat elektrik sebanyak 24 buah yang sudah diberi label yaitu P0 sampai P4: P0 (aquades), P1 (ekstrak daun 
kunyit 40ml/60 ml aquades), P2 (ekstrak daun kunyit $50 \mathrm{ml} / 50 \mathrm{ml}$ aquades), P3 (ekstrak daun kunyit $60 \mathrm{ml} / 40 \mathrm{ml}$ aquades), dan P4 (ekstrak daun kunyit $70 \mathrm{ml} / 30 \mathrm{ml}$ aquades). Selanjutnya alat elektrik yang telah berisi ekstrak daun kunyit tersebut dimasukkan ke dalam kotak dan dihidupkan terlebih dahulu selama 10 menit. Kotak uji memiliki ukuran $30 \mathrm{~cm}$ x $30 \mathrm{~cm}$ x $30 \mathrm{~cm}$ yang terbuat dari bahan fiber transparan di setiap sisinya serta terdapat lubang dengan diameter $10 \mathrm{~cm}$ untuk memasukkan alat elektrik dan nyamuk. Setelah 10 menit alat elektrik dihidupkan, nyamuk Culex sp. dimasukkan ke dalam kotak sebanyak 15 ekor yang masing-masing kotak telah diberi label sesuai perlakuan dan ulangan. Setelah itu lakukan pengamatan jumlah nyamuk Culex sp. yang mati setiap 1 jam sekali dalam 24 jam.

\section{Analisis Data}

Untuk analisis data hasil penelitian dipergunakan daftar analisis keragaman Rancangan Acak Lengkap (RAL).

\section{HASIL DAN PEMBAHASAN}

\section{A. Pengaruh Ekstrak Daun Kunyit (Curcuma Longa Linn.) terhadap Mortalitas Nyamuk Culex Sp.}

Berdasarkan hasil pengamatan pada nyamuk Culex sp. yang mengalami kontak langsung dengan ekstrak daun kunyit, kondisi nyamuk masih terbang dan menempel pada dinding kotak namun setelah itu mengalami kematian. Padasaat ekstrak daun kunyit yang dipanaskan dengan menggunakan alat elektrik tersebut mengeluarkankandungan metabolit sekunder berupa Flavonoid, minyak atsiri dan steroid.Adanya kandungan metabolit sekunder memberikan efek pada sistem pernafasan nyamuk yang berujung pada kematian (mortalitas) nyamuk. Konsentrasi ekstrak daun kunyit yang diberikan pada masing-masing perlakuan memberikan pengaruh yang berbeda terhadap jumlah mortalitas nyamuk Culex sp..Hasil pengujian jumlah mortalitas larva nyamuk Culex sp. yang diberi ekstrak daun kunyit (Curcuma longaLinn.) dapat dilihat pada Gambar 1.

Berdasarkan Gambar 1 di atas, dapat diketahui bahwa pada konsentrasi 0\% (kontrol) tidak terdapat kematian nyamuk Culex sp. Pada konsentrasi 40\% (40 ml ekstrak daun kunyit/ $60 \mathrm{ml}$ aquades) ratarata jumlah mortalitas nyamuk Culex sp. sebanyak 6,25 ekor. Pada konsentrasi 50\% (50 ml ekstrak daun kunyit/ $50 \mathrm{ml}$ aquades) rata-rata jumlah mortalitas nyamuk Culex sp. sebanyak 8,5 ekor. Pada konsentrasi 60\% (60 ml ekstrak daun kunyit/ $40 \mathrm{ml}$ aquades) rata-rata jumlah mortalitas nyamuk Culex sp. sebanyak 11,5 ekor dan pada konsentrasi 70\% (70 ml ekstrak daun kunyit/ $30 \mathrm{ml}$ aquades) rata-rata jumlah mortalitas nyamuk Culex sp. sebanyak 14,75 ekor. 


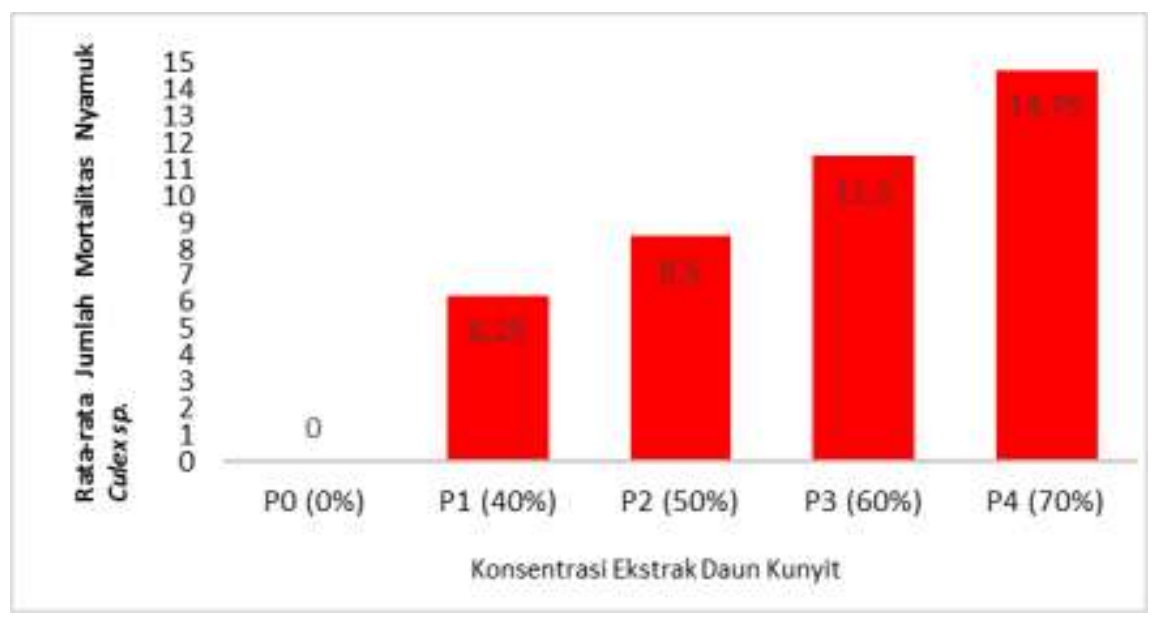

Gambar 1.Hasil Rata-rata Jumlah Mortalitas Nyamuk Culex sp. yang diberi Ekstrak Daun Kunyit (Curcuma longaLinn.)

Hal ini menunjukkan bahwa pemberian konsentrasi ekstrak daun kunyit (Curcuma longa Linn.) dengan konsentrasi $40 \%, \quad 50 \%, \quad 60 \%$ dan $70 \%$ dapat menyebabkan mortalitas nyamuk Culex sp. dan terjadi peningkatan mortalitas nyamuk Culex sp. mortalitas tertinggi terjadi pada perlakuan P4 dengan konsentrasi $70 \%$ mematikan sebanyak 14,75 nyamuk Culex sp. dari jumlah total nyamuk dan mortalitas terendah terjadi pada perlakuan P1 dengan konsentrasi $40 \%$ mematikan 6,25 nyamuk Culex sp. dari jumlah total nyamuk uji.

Hal ini disebabkan karena tiap-tiap konsentrasi ekstrak daun kunyit memiliki komposisi senyawa flavonoid, steroid dan minyak atsiri yang berbeda. Sehingga daya bunuh terhadap nyamuk Culex sp. berbeda tergantung pada banyak sedikitnya konsentrasi ekstrak daun kunyit yang digunakan.

\section{B. Konsentrasi Ekstrak Daun Kunyit (Curcuma Longa Linn.) yang Efektif Sebagai Insektisida Elektrik terhadap Mortalitas Nyamuk Culex Sp.}

Berdasarkan hasil uji analisis varian diketahui bahwa ada perbedaan yang berarti antar perlakuan yang dicoba. Untuk mengetahui perlakuan mana yang paling tinggi atau paling efektif dalam memberikan respon, dilakukan uji lanjut yaitu dengan Uji Beda Nyata Jujur (BNJ). Untuk melihat pengaruh pemberian ekstrak daun kunyit (Curcuma longaLinn.) sebagai insektisida elektrik terhadap mortalitas nyamuk Culex sp. di analisis menggunakan SPSS Versi 22.0 dapat dilihat pada Tabel 1 berikut. 
Tabel 1. Analisis Varian Pengaruh Pemberian Ekstrak Daun Kunyit (Curcuma longaLinn.) sebagai Insektisida Elektrik Terhadap Mortalitas Nyamuk Culex sp.

\begin{tabular}{lccccc}
\hline $\begin{array}{c}\text { Sumber } \\
\text { Keragaman }\end{array}$ & $\begin{array}{c}\text { Derajat } \\
\text { Bebas }\end{array}$ & $\begin{array}{c}\text { Jumlah } \\
\text { Kuadrat }\end{array}$ & $\begin{array}{c}\text { Kuadrat } \\
\text { Tengah }\end{array}$ & $\mathbf{F}_{\text {hitung }}$ & Sig \\
\hline Perlakuan & 4 & 499,700 & 124,925 & 535,393 & 0,000 \\
Galat & 15 & 3,5 & 0,233 & & \\
Total & 19 & 503,200 & & & \\
\hline Sumber: Pengolahan Data SPSS $22.0(2017)$. &
\end{tabular}

Tabel 2. Hasil Uji Beda Nyata Jujur (BNJ) Pengaruh Ekstrak Daun Kunyit (Curcuma longaLinn.) sebagai Insektisida Elektrik Terhadap Mortalitas Nyamuk Culex sp.

\begin{tabular}{|c|c|c|c|c|c|c|c|}
\hline \multirow[t]{2}{*}{ Perlakuan } & \multirow{2}{*}{$\begin{array}{c}\text { Konsent } \\
\text { rasi } \\
\text { ekstrak }\end{array}$} & \multirow{2}{*}{$\begin{array}{l}\text { Rata-rata } \\
\text { jumlah } \\
\text { mortalitas }\end{array}$} & \multicolumn{5}{|c|}{ Perlakuan } \\
\hline & & & P4 & P3 & $\mathbf{P 2}$ & P1 & P0 \\
\hline P0 & $0 \%$ & 0 & $\begin{array}{c}14,75^{*} \\
*\end{array}$ & $11,5^{* *}$ & $8,5^{* *}$ & $6,25 * *$ & - \\
\hline P1 & $40 \%$ & 6,25 & $8,5^{* *}$ & $5,25^{* *}$ & $2,25 * *$ & - & - \\
\hline $\mathrm{P} 2$ & $50 \%$ & 8,5 & $6,25^{* *}$ & $3 * *$ & - & - & - \\
\hline P3 & $60 \%$ & 11,5 & $3,25^{* *}$ & - & - & - & - \\
\hline $\mathrm{P} 4$ & $70 \%$ & 14,75 & - & - & - & - & - \\
\hline \multicolumn{3}{|c|}{ BNJ 0,05 = 0,985 } & \multicolumn{4}{|c|}{ BNJ 0,01= 1,267 } & \\
\hline
\end{tabular}

Hasil analisis sidik ragam pada Tabel 1 menunjukan nilai $F_{\text {hitung }}(535,393)>$ nilai sig. 0,000 yang dapat disimpulkan bahwa pemberian ekstrak daun kunyit berpengaruh sangat nyata terhadap mortalitas nyamuk Culex sp. Menurut Subiyakto (2005), racun masuk kedalam tubuh serangga melalui saluran pernapasan yang disebut spirakel dan pori-pori pada permukaan tubuh. Daya kerjanya menyerang pada sisem saraf dan cepat menimbulkan kelumpuhan serta kematian. Steroid bekerja sebagai racun saraf karenamempengaruhi neurotransmisi dan menghambat transpor ion.Karena system saraf nyamuk terganggu oleh masuknya senyawa steroid ke dalam tubuh nyamuk maka menyebabkan ganguan pada sistem saraf sehingga nyamuk lemas dan mengalami kematian (Hidana, 2015).
Menurut Hanafiah (2010), hasil perhitungan di atas menghasilkan nilai KK $=5,89 \%$. Nilai KK menunjukkan bahwa derajat ketepatan dalam suatu percobaan tertentu. Koefisien keragaman (KK) merupakan indeks keterandalan yang baik bagi suatu percobaan yang menunjukkan galat percobaan sebagai persentase dari nilai tengah.

Hasil uji BNJ pada Tabel 2 menunjukkan bahwa pemberian ekstrak daun kunyit (Curcuma longa Linn.) dengan berbagai konsentrasi berbeda sangat nyata antar perlakuan. Berdasarkan hasil pengamatan gejala yang teramati pada nyamuk Culex sp. yang mengalami kontak dengan ekstrak daun kunyit melalui organ pernapasan mengakibatkan keracunan. Hal ini sejalan dengan Wagutululy (2003), menyatakan bahwa faktor yang paling 
Aseptianova: Pengaruh Ekstrak Daun Kunyit (Curcuma longa Linn.) Sebagai Insektisida Elektrik Terhadap Mortalitas Nyamuk Culex sp. L.

menentukan potensi bahaya atau amannya suatu senyawa adalah hubungan antar kadar zat kimia dengan efek yang ditimbulkannya.

Iftitah (2016), menyatakan bahwa flavonoid berfungsi sebagai racun pernapasan atau inhibitor pernapasan sehingga saat nyamuk melakukan pernapasan flavonoid akan masuk bersama udara $\left(\mathrm{O}^{2}\right)$ melalui alat pernapasannya. Setelah melakukan pernapasan maka flavonoid akan menghambat sistem kerja pernapasan di dalam tubuh nyamuk. Racun pernafasan bahan insektisida biasanya bersifat menguap sehingga masuk kedalam tubuh nyamuk dalam bentuk gas. Racun pernafasan bekerja dengan cara menghalangi terjadinya respirasi tingkat seluler dalam tubuh nyamuk.

Menurut LA (2014), minyak atsiri berfungsi sebagai insektisida dan larvasida dengan cara kerja sebagai racun kontak (contac person) melalui permukaan tubuh hewan uji. Hal ini didukung pendapat Adityo (2013), menyatakan bahwa racun kontak dapat diaplikasikan langsung tertuju pada jasad sasaran atau pada permukaan tanaman pada tempat-tempat tertentu. Racun kontak yang telah melekat akan segera masuk kedalam tubuh dan disinilah mulai terjadi peracunan. Hasil uji fitokimia terhadap ekstrak etanol daun kunyit mengandung senyawa steroid/triterpenoid selain itu daun kunyit juga mengandung minyak atsiri dan flavonoid. Minyak atsiri merupakan turunan flavonoid berinteraksi dengan sel melalui proses absorpsi yang melibatkan ikatan hidrogen

Minyak atsiri daun kunyit terdiri atas komponen yang tergolong monoterpen, politerpen, alkohol, sesquiterpen, aldehid, keton, ester dan eter yang berfungsi sebagai repellent serta larvasida (Murdianti, 1998). Minyak atsiri merupakan turunan flavonoid berinteraksi dengan sel melalui proses absorpsi yang melibatkan ikatan hidrogen. Pada kadar tinggi flavonoid menyebabkan koagulasi protein dan sel membran mengalami lisis dan menyebabkan kematian larva Aedes aegypti (Tejasaputra, 2014).

Senyawa flavonoid bekerja sebagai racun inhalasi dengan masuk ke dalam mulut serangga melalui saluran pencernaan berupa spirakel yang terdapat di permukaan tubuh yang kemudian akan menimbulkan kelayuan pada saraf dan kerusakan pada spirakel, akibatnya serangga tidak bisa bernafas dan mati (Sitorus, 2015).

Untuk melihat pengaruh pemberian ekstrak daun kunyit (Curcuma longa Linn.) terhadap mortalitas nyamuk Culex sp. dapat dihitung dengan analisis probit, konsentrasi yang digunakan adalah $0 \%, 40 \%, 50 \%, 60 \%$ dan $70 \%$. Berbagai konsentrasi yang digunakan bertujuan untuk mengetahui nilai $\mathrm{LC}_{50}$. sedangkan waktu kematian yang dapat mematikan 50\% nyamuk Culex sp. dari jumlah total hewan uji dilakukan uji $\mathrm{LT}_{50}$. 


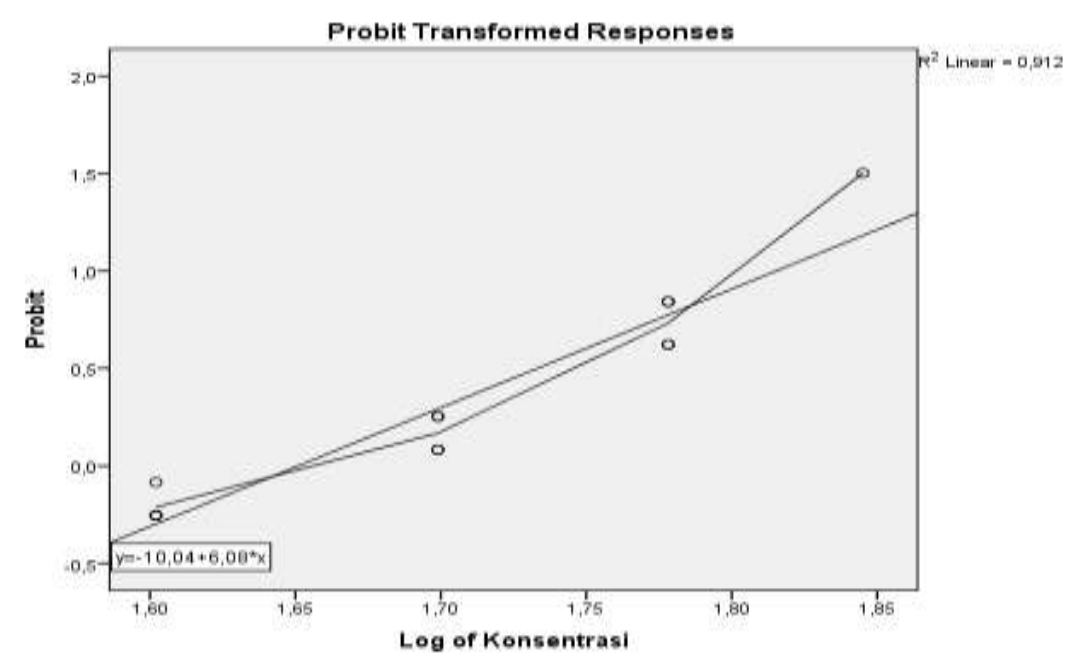

Gambar 2. Grafik LC $_{50}$ Ekstrak Daun Kunyit Terhadap Mortalitas Nyamuk Culex sp.

Grafik pada Gambar 2, ekstrak daun kunyit terhadap mortalitas nyamuk Culex sp. menunjukkan grafik secara linear, dengan nilai $\mathrm{R}^{2}$ adalah 0,912 artinya sebanyak 91,2\% mortalitas nyamuk Culex sp. disebabkan oleh ekstrak daun kunyit, sedangkan $8,8 \%$ disebabkan oleh faktor lain. Persamaan probit diperoleh $\mathrm{y}=\mathrm{a}+\mathrm{bx}$ adalah $\mathrm{y}=43,928+0,912 \mathrm{x}$ dari persamaan ini diperoleh persamaan ini diperoleh $\mathrm{x}$ sebesar 44,840 ml. semakin tinggi konsentrasi ekstrak daun kunyit yang diberikan maka semakin banyak nyamuk Culex sp. yang mati. Berbagai perlakuan konsentrasi yang diberikan didapat $\mathrm{LC}_{50}$ ekstrak daun kunyit terhadap mortalitas nyamuk adalah $44,840 \mathrm{ml}$, artinya pada konsentrasi $44,840 \mathrm{ml}$ telah terjadi mortalitas $50 \%$ dari total nyamuk.

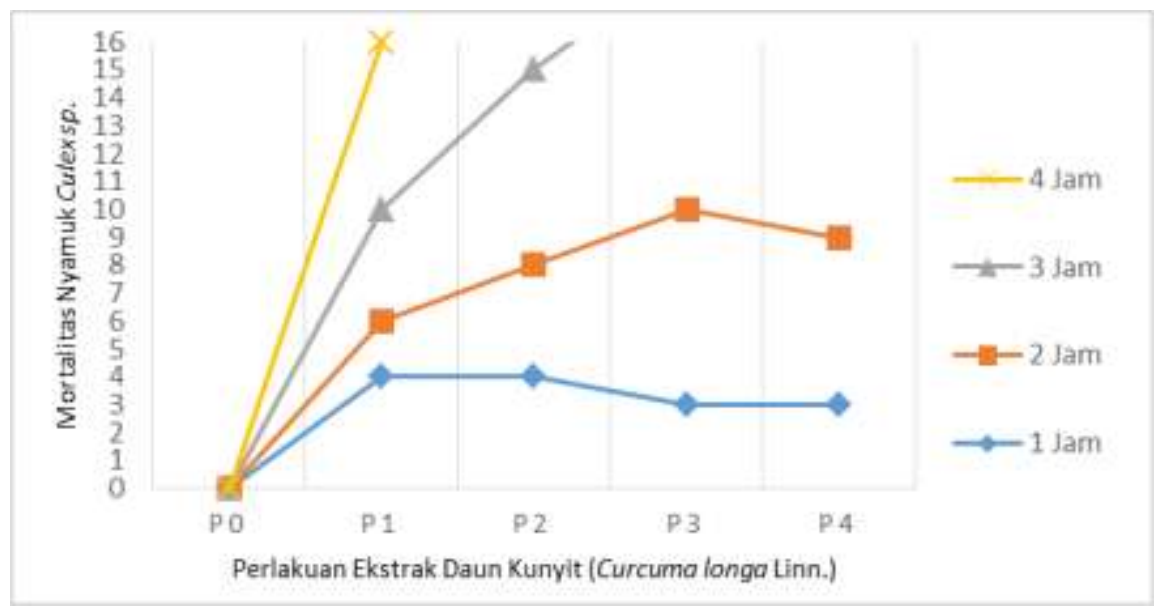

Gambar 3 Grafik Probit LT $_{50}$ Ekstrak Daun Kunyit terhadap Mortalitas Nyamuk Culex sp. 
Aseptianova: Pengaruh Ekstrak Daun Kunyit (Curcuma longa Linn.) Sebagai Insektisida Elektrik Terhadap Mortalitas Nyamuk Culex sp. L.

Berdasarkan Gambar 3 di atas, dapat diketahui jumlah mortalitas Culex sp. pada perlakuan P0 tidak terjadi kematian. Perlakuan P1 dengan konsentrasi $40 \%$ terjadi kematian pada jam 2,3,4 dengan waktu $\mathrm{LT}_{50}$ sebesar 4,4431 jam. Perlakuan P2 dengan konsentrasi $50 \%$ terjadi kematian pada jam 1,2,3,4 dengan waktu $\mathrm{LT}_{50}$ sebesar 3,096 jam. Perlakuan P3 dengan konsentrasi $60 \%$ terjadi kematian pada jam 1,2,3,4 dengan waktu $\mathrm{LT}_{50}$ sebesar 2,233 jam. Perlakuan P4 dengan konsentrasi $70 \%$ terjadi kematian pada jam 1,2,3,4 dengan waktu $\mathrm{LT}_{50}$ pada perlakuan P4 dengan konsentrasi 70\% sebesar 1,825 jam. Dilihat dari waktu kematian yang terjadi pada setiap perlakuan diperoleh waktu terendah pada perlakuan P1 dengan $\mathrm{LT}_{50}$ sebesar 4,4431 jam sedangkan waktu tercepat dalam membunuh nyamuk Culex sp. terjadi pada perlakuan $\mathrm{P} 4$ dengan $\mathrm{LT}_{50}$ sebesar 1,825 jam.

Nilai $\mathrm{LT}_{50}$ dan $\mathrm{LC}_{50}$ pemberian ekstrak daun kunyit terhadap mortalitas nyamuk Culex sp. menunjukkan adanya hubungan antar konsentrasi dan waktu. Berdasarkan perhitungan analisis probit $\mathrm{LC}_{50}$ dan $\mathrm{LT}_{50}$ dapat disimpulkan bahwa jika ingin membunuh $50 \%$ hewan uji maka menggunakan konsentrasi sebesar 44,840 ml sedangkan untuk mempercepat waktu kematian hewan uji dilakukan dengan pemberian konsentrasi yang lebih tinggi untuk mempersingkat waktu kematian hewan uji.

\section{KESIMPULAN}

Kesimpulan yang dapat ditarik dari penelitian pengaruh ekstrak daun kunyit (Curcuma longa Linn.) sebagai insektisida elektrik terhadap mortalitas nyamuk Culex sp. L. Adalah sebagai berikut.

1. Ekstrak daun kunyit (Curcuma longa Linn.) berpengaruh sangat nyata terhadap mortalitas nyamuk Culex sp. dengan nilai $F_{\text {hitung }}$ 535,393 lebih besar dari nilai sig. 0,000 .

2. Analisis probit $\mathrm{LC}_{50}$ ekstrak daun kunyit terhadap mortalitas Culex sp. L. adalah 44, $840 \mathrm{ml}$, artinya pada konsentrasi tersebut telah terjadi mortalitas $50 \%$ dari total nyamuk yang terjadi pada perlakuan P1 dan $\mathrm{P} 2$, sedangkan analisis probit $\mathrm{LT}_{50}$ ekstrak daun kunyit terhadap mortalitas Culex sp. L. sebesar 1,825 jam, yang berarti dalam waktu tersebut sudah dapat mematikan nyamuk Culex sp. $50 \%$ dari total nyamuk.

\section{DAFTAR PUSTAKA}

Adityo RHPP, Kurniawan B, dan Mustofa S. 2013. Uji efek fraksi ekstrak batang Kecombarang (Etlingera elatior) sebagai larvasida terhadap larva Instar III Aedes aegypti. 
Skripsi. Dipublikasikan. Universitas Lampung, Lampung.

Aseptianova A, Wijayanti TF, dan Nuraini Nita. 2017. Efektifitas pemanfaatan tanaman sebagai insektisida elektrik untuk mengendalikan nyamuk penular penyakit DBD. Bioeksperimen: Jurnal Penelitian Biologi, 3 (2): 10-19.

Caragay A-B. 1992. Cancer preventive food and ingredient. Foot Tech. Med. 65-68.

Galena G. 2014. Efek jangka panjang dan jangka pendek dari penggunaan cairan pembasmi nyamuk terhadap kesehatan manusia. Online at http://www. galena.co.id.

Hanafiah K. 2010. Rancangan Percobaan: Teori dan Aplikasi. Edisi revisi. Jakarta: PT Raja Grafindo Persada.

Hidana R dan Sani Novia. 2015. Efektivitas ekstrak daun Sereh (Cymbopogon nardus) sebagai antioviposisi terhadap nyamuk Aedes aegypti. Jurnal Kesehatan Bakti Tunas Husada, 13(1):133.

Iftitah I. 2016. Uji efektivitas rendaman daun Singkong (Manihot utilissima) sebagai insektisida terhadap nyamuk Aedes aegypti dengan metode elektrik cair. Jurnal Kesehatan Masyarakat (e-Journal), 4(2): 5-6.

LA Wijayani dan Isti'anah. 2014. Efek larvisidal ekstrak etanol daun Kemangi (Ocimum sanctum Linn) terhadap Larva Instar III Culex quinquefasciatus. Biomedika, 6 (2): 6-7.

Mirnawaty M, Supriadi, dan Budiman Jaya. 2012. Uji efektivitas ekstrak kulit langsat (Lansium domesticum) sebagai anti nyamuk elektrik terhadap nyamuk Aedes aegypti. J. Akad. Kim, 1 (4): 148.

Murdianti M. 1998. Mempelajari pengaruh ekstrak daun dan rimpang Kunyit (Curcuma longa Linn.) terhadap aktivitas sitolitik sel Natural Killer (NK) dalam melisis sel K-562 secara in vitro. Bogor: Fakultas Teknologi PertanianInstitut Pertanian Bogor.

Nindatu. 2011. Pengembangan Ekstrak Etanol Daun Lavender (Lavandula Angustifolia) Sebagai Anti nyamuk Vektor Filariasis CulexSp.Molucca Medica:Jurnal Kedokteran Dan Kesehatan. 4.1:20.

Oktiansyah O. 2015. Potensi ekstrak daun Salam (Syzygium polyanthum wight.) sebagai penolak nyamuk Culex quinquefasciatus say. dan sumbangannya pada pembelajaran biologi di SMA. Online at https://www.research gate.net/publication/280712846.

Palgunadi P. 2012.Aedes aegypti sebagai vector penyakit demam berdarah dengue. Online at http://dinus.ac.id.

Septiana E dan Partomuan Simanjuntak. 2015. Aktivitas antimikroba dan antioksidan ekstrak beberapa bagian tanaman Kunyit (Curcuma longa). Jurnal Fitofarmaka, 5(1): 31-40.

Sitorus MF, Wirsal Hasan, dan Irnawati Marsaulina. 2015. Pemanfaatan daun tanaman Sukun (Artocarpus altilis) sebagai anti nyamuk Mat Elektrik dalam membunuh Nyamuk Aedessp. Skripsi. Program Sarjana Fakultas Kesehatan Masyarakat Universitas. Sumatera Utara.

Subiyakto S. 2005. Cara praktis pembuatan pestisida nabati aman dan ramah lingkungan dengan teknik pengujian sederhana pestisida nabati dan pemanfaatannya. Yogyakarta: Kanisius.

Tejasaputra T. 2014. Daya insektisidal minyak Akar Wangi/ Vetiver Oil (Vetiveria zizanioides) sebagai bahan dasar obat nyamuk elektrik cair terhadap nyamuk Aedes aegypti. Yogyakarta: Universitas Gadjah Mada.

Utami GAP, Sri Rahayu Santi, dan Ni Made Puspawati. 2014. Minyak atsiri daun Tenggulun (Protium 
Aseptianova: Pengaruh Ekstrak Daun Kunyit (Curcuma longa Linn.) Sebagai Insektisida Elektrik Terhadap Mortalitas Nyamuk Culex sp. L.

javanicum Burm.F.) sebagai repelan nyamuk Demam Berdarah (Aedes aegypti). Jurnal Kimia, 8 (1): 74-75.

Wagutululy T. 2003. Uji toksisitas bioinsentisida ekstrak biji Mahkota Dewa (Phaleria papuana Warb.) terhadap mortalitas nyamuk Aedes aegyti Lin. Surabaya: Universitas Airlangga. 